\title{
SIMULATION OF CONDUCTIVE-CONVECTIVE HEAT TRANSFER IN A NATURAL BASIN
}

\author{
Petras Vaitiekūnas', Vladislovas Katinas ${ }^{2}$, Antanas Markevičius ${ }^{2}$ \\ ${ }^{1}$ Dept of Environmental Protection, Vilnius Gediminas Technical University, \\ Sauletekio al. 11, LT-10223 Vilnius-40, Lithuania. E-mail: vaitiek@itpa.lt \\ ${ }^{2}$ Lithuanian Energy Institute, Renewable Energy Laboratory, \\ Breslaujos g. 3, LT-44403 Kaunas-35, Lithuania \\ E-mail:res@isag.lei.lt,marke@isag.lei.lt
}

Received 3 Feb 2004; accepted 19 Mar 2004

\begin{abstract}
The state of water flow has been modelled numerically by a three-dimensional method of a complex investigation of heat and mass transfer. This allows examining interaction of some transfer processes in a natural cooling basin (the Drūkšiai lake): variable density of water, heat conduction in water-air interface, direct and diffuse solar radiation. Combined effect of these natural actions determines the heat amount that the basin is able to dissipate to the surrounding atmospheric media in thermal equilibrium (no change in the mean water temperature).

Mathematical model is simplified ignoring transient derivatives in transfer equations, and time as a variable is included in relaxation coefficients for outer iterations. Full time of calculations using this simulation mechanism for this variable is about $6 \mathrm{~h}$.

Basing on water stream velocity and mean temperature profiles measured in the cooling pond as well as on their time variations, suggestions are made that the mixing rate in water is caused by natural and forced convection. Comparison of experimental and numerical results showed a qualitative agreement. For a better quantitative approximation, it is necessary to have more boundary conditions variable with time and to solve unsteady set equations for transfer processes.
\end{abstract}

Keywords: Computational Fluid Dynamics (CFD), numerical simulation, three-dimensional processes, one-phase flows, hydrodynamics, lake as a cooler, heat exchange.

\section{Introduction}

Hydrothermal processes in a cooling pond are determined by heat and mass exchange at water-air interface, together with thermal processes inside the water volume of the pond. Inverse relations are observed between the two sets of processes, as the surface temperature determines the intensity of cooling, and this influences the temperature field of the pond together with the conditions of different stratification densities of streams and turbulent transfer [1].

The success of a mathematical simulation based on general relations of transport may depend on a correct problem statement on the basis of a correct choise of adequate initial conditions. The most important conditions for both remote regions and the whole cooling pond are: heat transfer to the atmosphere, the parameters of turbulence, heat balance, that is loss and increase of the heat. The former terms are found from convection, turbulent heat transfer, evaporation and inverse radiation in a long-wave spectrum. An increase of heat occurs whenever a volume of heated water is discharged from a thermal or nuclear power plant as well as by solar and atmospheric radiation [1, 2].

The hydrodynamics of the natural basin is modelled in [3] and heat transfer with the wind influence - in [4, 5]. The aim of this paper is applying CFD codes [6-8] to present a simulation of a mathematical model of hydrothermal processes in a cooling pond, including the effects of three-dimensional (3D) structure features of transport, temperature-dependent water density, heat convection in the water area, conduction at water-air interface, direct and diffuse solar radiation.

\section{Solution techniques and governing equations}

In a general approach with recirculation of streams and heat transfer, the problem is solved as the $3 \mathrm{D}$ set of the Navier-Stokes equations and energy equation for a theoretical model. The general expression is $[6,7]$ :

$$
\operatorname{div}\left(\rho \overrightarrow{\mathbf{V}} \Phi-\Gamma_{\Phi} \operatorname{grad} \Phi\right)=S_{\Phi},
$$

where $\rho$ - density, $\mathrm{kg} / \mathrm{m}^{3} ; \Phi-$ dependent variable: $\Phi=1-$ for continuity equation, $U, V, W-$ for impulse 
in directions $x, y$ and $z, \mathrm{~m} / \mathrm{s} ; H$ - for enthalpy; $\overrightarrow{\mathbf{V}} \quad-$ velocity vector; $\Gamma_{\Phi}$ - exchange coefficient of variable $\Phi ; S_{\Phi}$ - source term in the flow for variable $\Phi$.

The set of (1) consists of differential equations with partial derivatives of Navier-Stokes and heat transfer, and is solved by the technique of finite volumes with specific boundary conditions [3, 4]: inlet velocity $U_{0}=0,2 \mathrm{~m} / \mathrm{s}, t_{0}=36{ }^{\circ} \mathrm{C}$, air temperature $t_{a}=25,9{ }^{\circ} \mathrm{C}$, $U=V=W=0$ at solid walls and walls are adiabatic.

The real properties of water will be implemented for accounting the existent links between its density, heat capacity, thermal conductivity etc and temperature (water in a liquid state). This linking, and the establishment of conditions that simulate the action of gravity, will establish conditions for possible formation of natural convection phenomenon and buoyancy forces.

The program codes used evaluate the density of water as a function of temperature $t[6,7]$ :

$$
\begin{aligned}
\rho & =\left(999,83952+16,945176 t-7,9870401 \cdot 10^{-3} t^{2}\right. \\
& -46,170461 \cdot 10^{-6} t^{3}+105,56302 \cdot 10^{-9} t^{4} \\
- & \left.280,54253 \cdot 10^{-12} t^{5}\right) /\left(1+16,879850 \cdot 10^{-3} t\right),
\end{aligned}
$$

where $\rho$ - density $\mathrm{kg} / \mathrm{m}^{3}, t$ - temperature ${ }^{\circ} \mathrm{C}$.

The existence of a density gradient combined with a body force as the gravity action may cause a buoyancy force responsible for a free convection phenomenon which may be important in fluid motion. However, it will be a good approximation to consider constant other water properties, as thermal conductivity or heat capacity because of a less effect of their respective gradients on fluid motion.

Surface exchange. Considering the adiabatic bottom and walls of the basin, the only capacity of thermal dissipation of the mass of water occurs by means of heat exchange at the surface with the atmosphere. The main factors considered (convection, conduction, direct and diffuse solar radiation) which will determine as much the global distribution of temperature as the amount of total dissipated energy. Addition of the net effects of these energetic factors will represent the amount of global energy that the basin surface is capable to dissipate.

We will study the distribution of temperature at the surface of the basin because, although the global mean temperature of the basin may increase, it does not mean that could not be appreciated certain change of temperature at the station cooling water intake.

The incidence of the water stream over the basin surface implicates the inclusion of convective-conductive heat transfer factors over the basin surface. The heat transfer rate by conduction between air and water that governs this situation has the form [6]:

$$
\mathbf{q}=\alpha\left(t_{\text {water }}-t_{\text {air }}\right) \text {, }
$$

where $\mathbf{q}$ represents heat flow $\left(\mathrm{W} / \mathrm{m}^{2}\right)$ which is proportional to temperature differences between water and air.
The proportionality constant a represents all the factors that influence conductive-convective heat transfer. Heat transfer due to the incidence of the atmospheric air on the surface could be represented by means of a coefficient a of the form [7]:

$$
\alpha=f\left(S t, \rho_{a}, V_{r e l}, c_{p a}\right),
$$

where $\rho_{a}$ is air density, $V_{\text {rel }}$ is relative velocity between air and water, $V_{r e l}>0[6], c_{p a}$ is the specific heat of air, $S t$ is the Stanton number. In a reposed air-water interface it has an approximated value of $S t \approx 0,0033$ and $\mathbf{q}$ is calculated according to [6].

If we have the following values: $\rho_{a}=1,2 \mathrm{~kg} / \mathrm{m}^{3}$, $c_{p a}=1005 \mathrm{~J} /(\mathrm{kg} \mathrm{K}), V_{r e l}=0,1 \mathrm{~m} / \mathrm{s}$, then we will obtain the following value of $(4): \alpha \approx 0,362, \mathrm{~W} /\left(\mathrm{m}^{2} \mathrm{~K}\right)$.

Incidence of direct solar radiation. The incidence of direct solar radiation over the basin surface induces the heating of water; its value depends on its specific heat at a constant pressure $\left(c_{p a}=4183 \mathrm{~J} /(\mathrm{kg} \cdot \mathrm{K})\right.$, so that $q_{\text {sun }}=c_{p a} T$, where $T$ is temperature $\mathrm{K}$. The values of $q_{\text {sun }}$ in Ignalina (Lithuania) are picked up from Table 1.

Table 1. Values of mean solar intensity $\left(\mathrm{S}^{\mathrm{I}}\right)$ on horizontal in a mean day of every month in Ignalina

\begin{tabular}{|l|c|c|c|c|c|c|}
\hline Month & I & II & III & IV & V & VI \\
\hline$S^{I}, \mathrm{~W} / \mathrm{m}^{2}$ & 70 & 200 & 240 & 316 & 392 & 436 \\
\hline Month & VII & VIII & IX & X & XI & XII \\
\hline$S^{I}, \mathrm{~W} / \mathrm{m}^{2}$ & 402 & 326 & 275 & 170 & 100 & 70 \\
\hline
\end{tabular}

The effects of these incidences will be affected by optical reflection over the surface represented by a determined index (not the whole incident energy is transmitted and absorbed). Only part of the net energy that impinges on the surface of the basin (Table 2) is used for increasing the heat of water. The residual energy is lost in the form of reflected energy. This factor will depend on the incidence angle of the solar beam and the refraction index of water $n=1,33$ (ignoring its wavelength dependence). Both contributions are related with each other by means of the Frenel laws. The incident radiation fraction that penetrates the basin surface $(P)$ and is absorbed by water for its posterior transformation in heat is expressed in the Frenel formula $[6,7]$ :

$$
P=1-\frac{1}{2}\left[\frac{\sin ^{2}\left(z-\theta_{r}\right)}{\sin ^{2}\left(z+\theta_{r}\right)}+\frac{\operatorname{tg}^{2}\left(z-\theta_{r}\right)}{\operatorname{tg}^{2}\left(z+\theta_{r}\right)}\right],
$$

where $\theta_{r}$ is refraction angle on the water surface, $z$ is zenithal solar distance $\left(90^{\circ}-\right.$ solar altitude). We will also use the Snell refraction law in order to determine $\theta_{r}$ as a function of the refraction index $n$ and the solar zenithal distance $z$ :

$$
n \sin \theta_{r}=\sin z .
$$

Particularizing for Ignalina, the values of the monthly solar altitude were calculated from equation (8). 
Incidence of diffuse solar radiation. Diffuse solar radiation is also an important factor, since its value oscillates from $13 \%$ of direct radiation incidence for a high solar altitude $\left(90^{\circ}\right)$ to $150 \%$ for rather smaller altitudes (Table 2).

On clear days the next experimental table could be established which relates the solar altitude with the direct radiation fraction that constitutes diffuse radiation. The data of Table 2 are fitted by means of an equation that relate the solar altitude and the percentage of direct radiation [7]. The adjustment equation that will be used in the program in order to determine diffuse radiation is of the form:

$$
I_{\text {solar }}, \%=a+b / h, a=2,807, b=727,1,
$$

$h=\arcsin (\cos \varphi \cos \delta \cos \gamma+\sin \varphi \sin \delta)$,

where $h$ is solar altitude $\left(^{\circ}\right), \gamma$ is solar hourly angle $\left(^{\circ}\right)$, $\varphi$ is geographical latitude $\left(^{\circ}\right), \delta$ is solar declination $\left(^{\circ}\right)$ : $\delta=23,5 \cos (30 K-187)$ and $K$ is number of month set $(1,2, \ldots, 12)$.

Consequently, we will introduce a source of additional radiation the value of which will be a determined percentage of direct incident radiation and this will establish the effect of diffuse radiation over the basin surface.

Table 2. Percentage of direct radiation which constitutes diffuse radiation as a function of the solar altitude

\begin{tabular}{|c|c|c|c|}
\hline Solar altitude & $I_{\text {solar }} \%$ & Solar altitude & $I_{\text {solar }} \%$ \\
\hline 5 & 148,0 & 50 & 17,24 \\
\hline 10 & 75,5 & 55 & 16,02 \\
\hline 15 & 51,3 & 60 & 14,93 \\
\hline 20 & 39,16 & 65 & 13,99 \\
\hline 25 & 31,89 & 70 & 13,19 \\
\hline 30 & 27,04 & 75 & 12,50 \\
\hline 35 & 23,58 & 80 & 11,89 \\
\hline 40 & 20,98 & 85 & 11,36 \\
\hline 45 & 18,96 & 90 & 10,89 \\
\hline
\end{tabular}

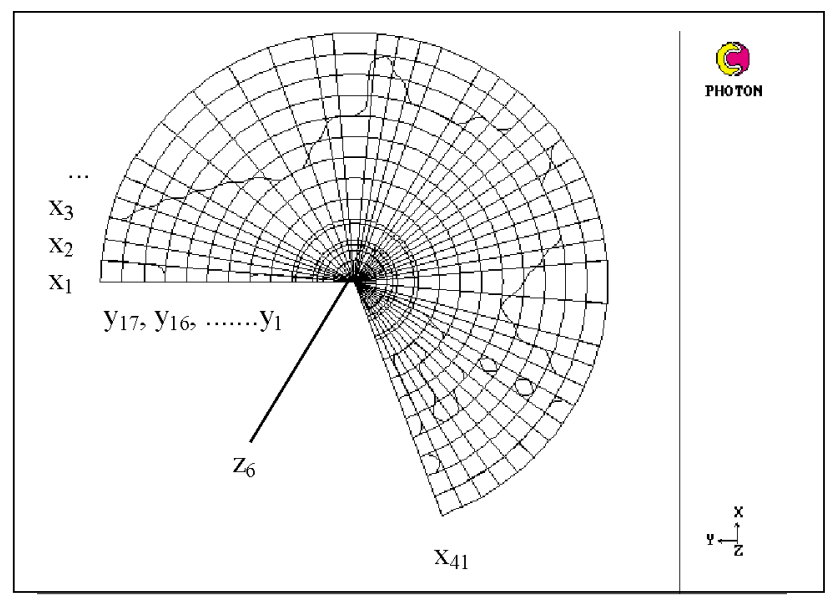

Fig 1. Difference grid in cylindrical co-ordinates $(x \cdot y \cdot z=$ $41 \cdot 17 \cdot 6)$. 2D representation at $z_{6}=$ const plane
In our computation we divided the range of integration by a normal line. One of the parts contained 6 horizontal layers in the volume of water and was intended for evaluating the geometry of the shoreline and depth. The parameters of the pond, hot-water plume and cool water return must be as close as possible to actual values. In our study we used the flow rate of hot water discharge.

\section{Results and consideration}

Therefore, a variable-step grid was constructed (Fig 1). It covers only a certain part of the surface, and the range of integration with respect to the normal covers a $10 \mathrm{~m}$ layer of water (with blocking cells). The cross section of the intake and outflow channel is $150 \cdot 2,5, \mathrm{~m}^{2}$, intake velocity $U_{0}=0,2 \mathrm{~m} / \mathrm{s}$, discharge rate $G=80 \mathrm{~m}^{3} / \mathrm{s}$.

In this case we evaluated the effect of factors on the hydrothermal behaviour of the lake which come into the play by influence on the distribution of isotherms. The technique of testing was applied from [2]. Temperature dependence was evaluated for water density according to experimental correlation (2), the water-air heat conduction, direct and diffuse solar radiation. Numerical simulation of $41 \cdot 17 \cdot 6$ cylindrical grid system consumes a lot of computer time, therefore, computation was suspended whenever a specific effect of wind became evident $[3,4]$ or similar to measured data at hotwater discharge [5]. A closer agreement for temperature field on the water surface was found for the case of no wind. In Fig 2 presented intermediate simulated results and in Fig 3 - final for comparison with measured results. Time for these calculations (a full time scale replacing a transient iterative process by FALSDT [8] for outer relaxation) is $21600 \mathrm{~s}$, i e $6 \mathrm{~h}$.

A numerical experiment to show solar radiation factor impact on the basin heat exchange was performed. The results of the experiment with local temperatures $\left(t^{\circ} \mathrm{C}\right)$ are presented in Table 3, the location co-ordinates of the basin (see Fig 1) are $x_{3}, y_{i,}(i=1,2, \ldots, 17), z_{6}=$ constant. The co-ordinates are given for a basin sector near the intake of the water canal. The boundary conditions of the experiment are the following: calm air temperature is $25,9{ }^{\circ} \mathrm{C}$, inlet water temperature $-36{ }^{\circ} \mathrm{C}$, mean direct day solar radiation intensity in june according to Table $1-400 \mathrm{~W} / \mathrm{m}^{2}$, diffuse solar radiation intensity $-100 \mathrm{~W} / \mathrm{m}^{2}$, air humidity $-75 \%$, water discharge rate $G=80 \mathrm{~m}^{3} / \mathrm{s}$.

Table 3. Predicted results of the basin heat exchange, local temperatures, ${ }^{\circ} \mathrm{C}$

\begin{tabular}{|c|c|c|c|c|c|c|}
\hline & \multicolumn{6}{|c|}{$y_{i} i=1,2, \ldots, 17$} \\
\hline & 14 & 12 & 10 & 8 & 6 & 4 \\
\hline 1 & 27,77 & 27,96 & 27,56 & 26,12 & 26,08 & 26,20 \\
\hline 2 & 27,59 & 27,56 & 27,36 & 26,04 & 25,90 & 25,96 \\
\hline 3 & 27,73 & 27,91 & 27,51 & 26.10 & 26,03 & 26,15 \\
\hline
\end{tabular}




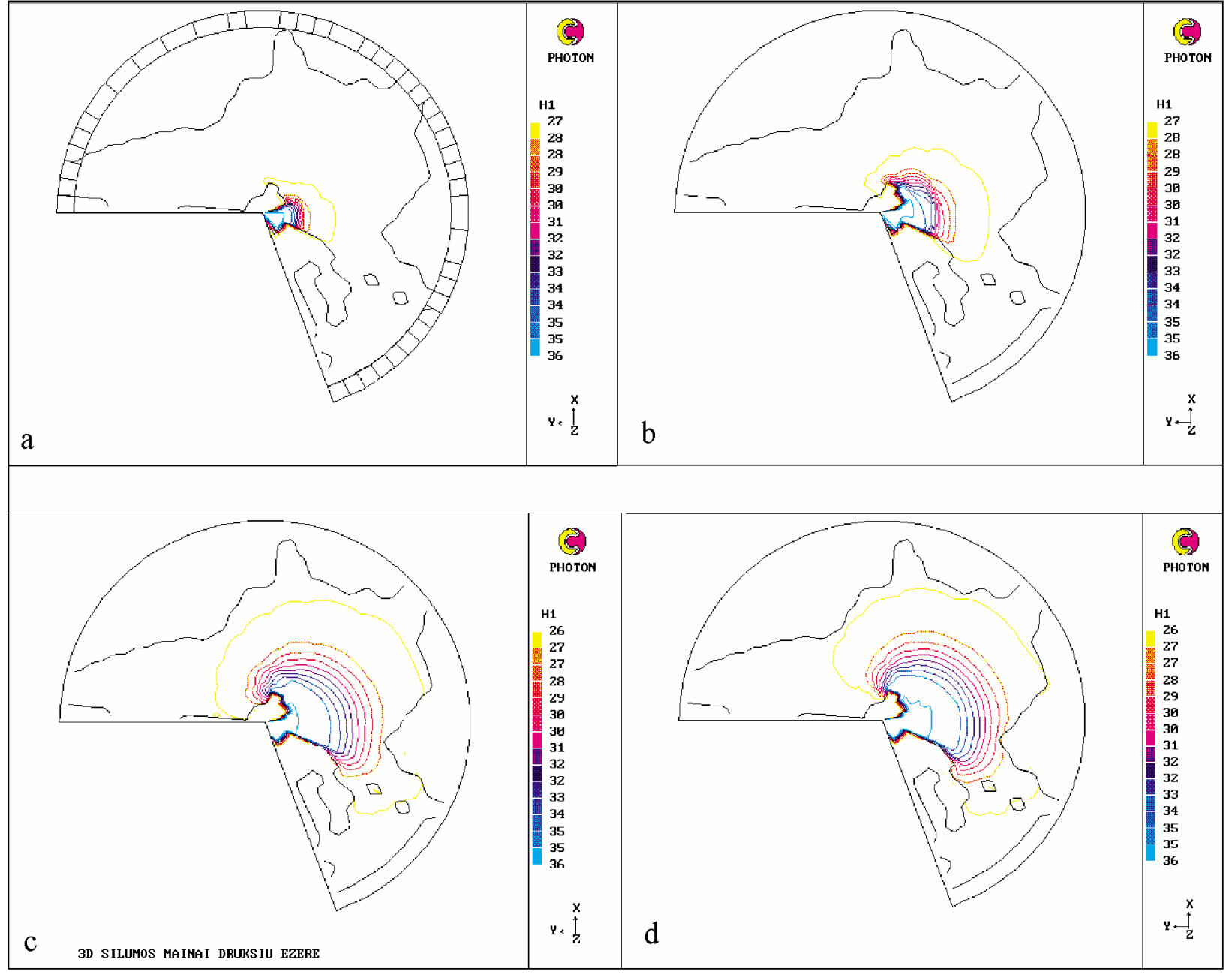

Fig 2. Predicted results of the heat transfer process in a cooling pond (no wind): a - isoterms during time $t_{1}=0,5 \mathrm{~h} ; \mathrm{b}-$ $t_{2}=1 \mathrm{~h} ; \mathrm{c}-t_{3}=2 \mathrm{~h} ; \mathrm{d}-t_{4}=2,5 \mathrm{~h}$

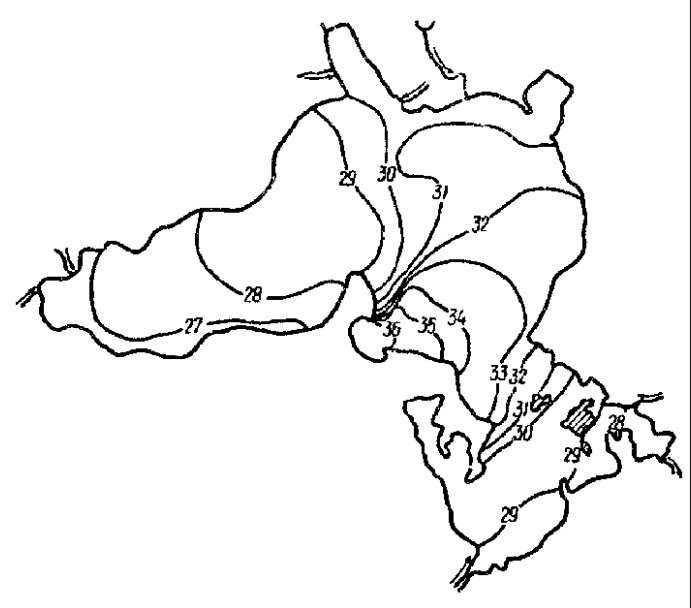

a

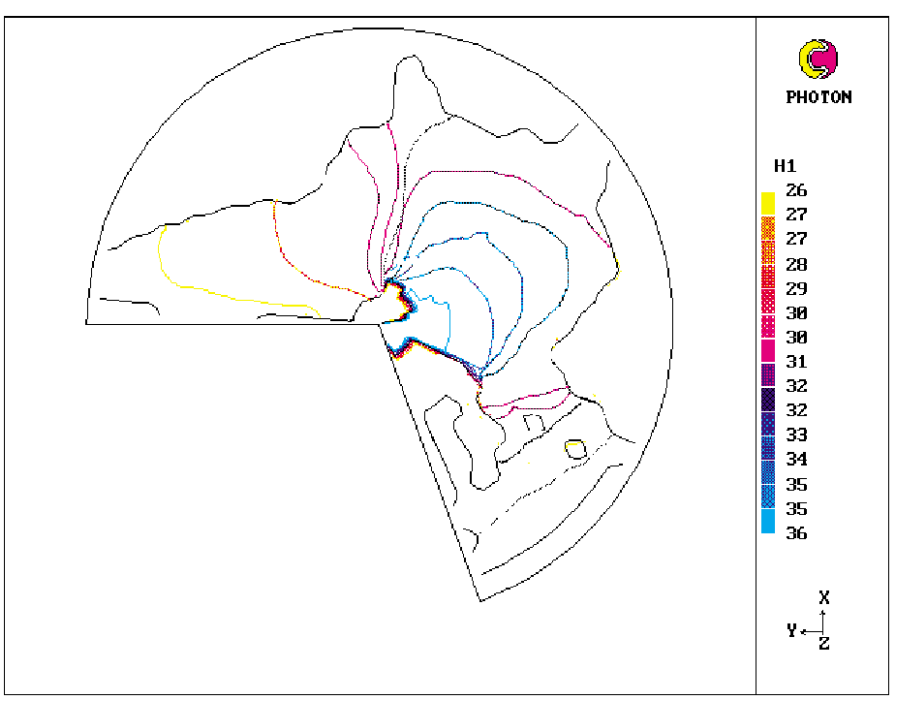

b

Fig 3. The Drūkšiai lake water surface isotherms during the time $t_{5}=6 \mathrm{~h}$ (no wind), a - measured isotherms [2], $\mathrm{b}-$ predicted isotherms. Initial temperature conditions: for water mass $-22{ }^{\circ} \mathrm{C}$, for water inlet $-36{ }^{\circ} \mathrm{C}$, for air temperature $25,9{ }^{\circ} \mathrm{C}, H 1 \equiv t^{\circ} \mathrm{C}$ 
In Table 3 row 1 presents a numerical experiment which assesses all heat exchange mechanisms: by convection, by conductivity of water-air plus direct and diffuse solar radiation over the basin surface; row 2 - temperatures without direct solar radiation effects, row $3-$ temperatures without diffuse solar radiation effects.

The most important factor having an influence on the heat exchange of the basin is conductive heat transfer between water and air, although differences in the temperature of air and water are moderate. The second important factor affecting the heat exchange of the basin on a sunny day is direct solar radiation - $-0,6-0,9 \%$ (Table 3). Diffuse solar radiation has a smaller influence on heat exchange - 0,1-0,2 \%. These last two effects in heat balance are negligible and can be ignored in convective-conductive heat dissipation in a cooling pond.

\section{Conclusions}

1. A mathematical model is simplified ignoring transient derivatives in transfer equations, and time as a variable is included in relaxation coefficients for outer iterations. Full time of calculations using this simulation mechanism for this variable is about $6 \mathrm{~h}$.

2. The most important factor having an influence on the heat exchange of the basin is convection in the water area and conductive heat transfer between water and air.

3. An analysis of numerical solutions for hydro-thermal processes in the Drūkšiai lake and their comparison with the test points are good. To approach the prediction to the actual state possible time-dependent boundary conditions should be included.

\section{References}

1. Drižius, M. R. Hydrothermics of cooling ponds (Гидротермический режим водохранилищ-охладителей). Vilnius: Mokslas, 1985. 107 p. (in Russian).

2. Ecosystem of the cooling pond of the Ignalina Nuclear Power Station in the initial period of its operation (Ignalinos atominès elektrinès šaldomojo tvenkinio ekosistemos būklè pradiniu jos eksploatacijos periodu). T. 10. D. 1. Vilnius: Akademija, 1992. 246 p (in Lithuanian).

3. Baltrènas, P.; Vaitiekūnas, P.; Petkevičiené, J. Numerical simulation of hydrodynamic processes in the lake of Drūkšiai. Environmental Engineering (Aplinkos inžinerija), Vol IX, No 2, Vilnius: Technika, 2001, p 117-123.

4. Vaitiekūnas, P.; Petkevičienè, J.; Katinas, V. Numerical simulation of heat exchange in a cooling pond. Environmental Engineering (Aplinkos inžinerija), Vol X, No 2, Vilnius: Technika, 2002, p 5-60 (in Lithuanian).

5. Vaitiekūnas, P.; Petkevičienè, J.; Katinas, V. A Numerical simulation of three-dimensional hydrothermal Proces-ses in a cooling pond. The PHOENICS Journal of Computational Fluid Dynamics \& its Applications, Vol 11, No 3, 1998, p 348-354.

6. Montenegro, H. S.; Choucino, M. A. Thermal dissipation in a natural basin. The PHOENICS Journal of Computational Fluid Dynamics \& its Applications, Vol 7, No 3, 1994, p 14-36.
7. Vaitiekūnas, P.; Petkevičienè, J.; Katinas, V. Numerical simulation of hydrothermal processes in the Drūkšiai lake. Computational procedure. Power Engineering (Energetika). No 4. Vilnius: Publishing house of Lithuanian Academy of Sciences, 2000, p 42-52 (in Lithuanian).

8. PHOENICS 3.5 VR. 2002. http//www.cham.co.uk

\section{ŠILUMOS LAIDUMO-KONVEKCINIŲ MAINU NATŪRALIAME BASEINE MODELIAVIMAS}

\section{P. Vaitiekūnas, V. Katinas, A. Markevičius}

Santrauka

Matematinis vandens srauto modelis sudarytas skaitiniam trimačiu pernašos procesų vienfaziame fluide modeliavimui. Nagrinejjama i̇vairių veiksnių bei jų sąveikos įtaka pernašos procesams, masès ir šilumos mainams natūriniame baseineaušintuve: vandens tankio priklausomybè nuo temperatūros, konvekcija-laidumas vandens masèje, šilumos laidumo mainai su oro aplinka, tiesioginè ir sklaidžioji saulès spinduliuotė.

Matematinis modelis supaprastintas atmetant nenuostovumo narius pernašos lygtyse, laiko kintamaji ivedant kaip išorinių iteracijų relaksacijos koeficientus. Skaičiavimo trukmè - apie $6 \mathrm{~h}$.

Palyginus eksperimentinius ir teorinius rezultatus paaiškejjo kokybinis ju sutapimas. Kad kiekybiniai rezultatai sutaptu tiksliau, reikètų turèti daugiau i̇vairių veiksnių ribinių sąlygų, kintančių laike, bei spręsti nenuostoviąsias pernašos lygtis.

Raktažodžiai: hidrodinamika, skaičiuojamoji fluidų dinamika, skaitinis modeliavimas, trimačiai procesai, vienfaziai srautai, baseinas-aušintuvas, šilumos mainai.

\section{МОДЕЛИРОВАНИЕ КОНДУКТИВНО- КОНВЕКТИВНОГО ТЕПЛООБМЕНА В НАТУРАЛЬНОМ БАССЕЙНЕ}

\section{П. Вайтекунас, В. Катинас, А. Маркявичюс}

Р е $з$ ю м е

Составлена математическая модель для численного моделирования трехмерных процессов переноса тепла в однофазном флуиде. Исследуется взаимосвязь факторов, влияющих на процессы переноса, их влияние на теплообмен в натуральном бассейне-охладителе: переменная плотность воды, конвективно-кондуктивный теплообмен, прямая и диффузионная солнечная радиация.

Математическая модель упрощена исключением временных частных производных в уравнениях переноса, включением временной переменной в релаксационные коэффициенты внешней итерации. В общей сложности повременной переменной отводится около 6 ч.

Сравнение теоретических и экспериментальных результатов показало их качественное совпадение. Для более точного количественного совпадения необходимо иметь больше граничных условий, изменяющихся во времени, и решать нестационарные уравнения переноса.

Ключевые слова: гидродинамика, вычислительная динамика жидкостей, численное моделирование, трехмерные процессы, однофазный поток, озеро-охладитель, теплообмен. 